\title{
Occurrence of Tospoviruses in Ornamental and Weed Species in Markazi and Tehran Provinces in Iran
}

\author{
T. Ghotbi, Science and Research Division, Islamic Azad University, Tehran, Iran; N. Shahraeen, Department of \\ Plant Virus Research, Plant Pests and Disease Research Institute (PPDRI), Agricultural Research and Education Or- \\ ganization, Tehran, Iran; and S. Winter, DSMZ Plant Virus Division, c/o BBA, 38104 Braunschweig, Germany
}

\begin{abstract}
Ghotbi, T., Shahraeen, N., and Winter, S. 2005. Occurrence of tospoviruses in ornamental and weed species in Markazi and Tehran provinces in Iran. Plant Dis. 89:425-429.

Damage to agricultural crops by tospoviruses has occurred sporadically in Iran in the past; however, since 2000, outbreaks of tospoviruses have been recorded every year. The most affected ornamental crops were surveyed in two main cultivation areas in provinces of Markazi (Mahallat) and Tehran in 2000-01 and 2001-02. A few weed species also were collected. In all, 513 samples (with or without any conspicuous virus symptoms) were collected and analyzed by double- and triple-antibody sandwich enzyme-linked immunosorbent assay (ELISA) with polyclonal antibodies to Tomato spotted wilt virus (TSWV), Impatiens necrotic spot virus (INSV), and Tomato Varamin virus (ToVV), a new Tospovirus sp. from Iran. These viruses frequently were detected in samples of many different ornamentals and often in mixed infections, whereas Iris yellow spot virus (IYSV) was detected in only four samples. ToVV also was found in weeds growing in Chrysanthemum fields and in a Cuscuta sp. Applying double-antibody sandwich ELISA, no positive reactions were found with Tomato chlorotic spot virus (TCSV). Of the total of 513 samples tested, 345 samples did not react with any Tospovirus antisera. In Tehran, INSV was identified in 21 samples (10\%), IYSV in 4 samples (2\%), TSWV in 16 samples (8\%), and ToVV in 22 samples (11\%). In Markazi province, INSV was identified in 24 samples (8\%), IYSV in 1 sample $(0.5 \%)$, TSWV in 40 samples (13\%), and ToVV in 36 samples (12\%). ToVV was found to prevail in Tehran province and TSWV in Markazi. Thrips spp. present at the plant sampling sites also were collected and identified.
\end{abstract}

Tospovirus spp. are of increasing importance worldwide in crop and ornamental plants (17). In recent years, considerable diversity has been found within the genus Tospovirus in the family Bunyaviridae, with at least 12 distinct species described on the basis of serological relationships, host range and vector relationships, and comparison of nucleotide and amino acid sequences of the $L, M$, and $S$ genes $(3,6,9,13,14)$. Diseases caused by tospoviruses are endemic in Iran. In the past, damage has occurred sporadically in cultivated crops such as soybean (Glycine max L.), tomato (Lycopersicon esculentum Mill.), potato (Solanum tuberosum L.), tobacco (Nicotiana tabacum L.), and peanut (Arachis hypogaea L.) $(2,8,10,15,17,19)$. Economic losses caused by tospoviruses in

Corresponding author: N. Shahraeen

E-mail: shahraeen@yahoo.com

Part of this research is funded by the PPDRI research project No. 100-11-79-092.

Accepted for publication 7 October 2004.

DOI: 10.1094/PD-89-0425

(C) 2005 The American Phytopathological Society
Iran are unknown, but infection levels can reach up to $100 \%$, as shown for Tomato spotted wilt virus (TSWV) in a glasshousegrown crop of Cineraria spp. (15). In the Varamin (Tehran province) area, $17 \%$ yield loss to TSWV was estimated in susceptible tomato cultivars (12). Markazi (Mahallat) and Tehran provinces are the two main cultivation regions for ornamental crops in Iran (Fig. 1). These regions are located 270 $\mathrm{km}$ apart and are 1,747 and 1,200 $\mathrm{m}$ above sea level, respectively (Fig. 1). The area under cultivation of ornamentals in Iran is 4,100 ha, of which approximately 900 ha are in Markazi and 1,100 ha are in Tehran province (1). Smaller acreages of various food legumes and other vegetable crops (primarily crucifers) also are grown in these regions. The aim of the present study was to gain an insight into the occurrence and distribution of different tospoviruses and their role as disease agent in affected ornamentals, and to identify the Thrips spp. present in infected areas.

\section{MATERIALS AND METHODS}

Survey. In all, 513 samples were collected in 2000-02 from fields and glasshouses in Tehran (207 samples) and Markazi (306 samples) provinces (Table
1). Samples were collected from 32 plant families and 53 plant species. Samples comprised leaves and stems of ornamentals and flowering weeds that either exhibited various symptom types or were without any conspicuous symptoms. About $15 \%$ of the samples were asymptomatic.

Collection and identification of Thrips spp. Thrips populations were collected from the same areas as virus-infected plants. After collection, some thrips initially were stored in a mixture of $60 \%$ ethanol, glycerol, and acetic acid (9:1:1) for later mounting and identification. Double-antibody sandwich enzyme-linked immunosorbent assay (DAS-ELISA) was used to detect virus in individual adult thrips as described by Cho et al. (4).

Serological testing, sap inoculations, and electron microscopy. Standard DASELISA (5) was performed with polyclonal antisera raised against the nucleocapsid (N) protein for Iris yellow spot virus (IYSV), Tomato chlorotic spot virus (TCSV), and Tomato Varamin virus (ToVV; synonym: Tomato yellow fruit ring virus [TYFRV]), a newly proposed Tospovirus species (21; accession nos. AJ493270 and AJ493271, EMBL/ GenBank/DDBJ databases). Triple-antibody sandwich (TAS)-ELISA was performed with monoclonal antiserum against TSWV and Impatiens necrotic spot virus (INSV) (7). All serological reagents against tospoviruses used were from the DSMZ (Brauncheweig, Germany) plant virus antiserum collection: TSWV (AS0115, AS-0106/0116 Mab-IgG), ToVV (AS-0526), INSV (AS-0115, 0117/1MabIgG), IYSV (AS-0528), and TCSV (AS0195), including the respective positive controls in each ELISA. Absorbance at $405 \mathrm{~nm}$ was measured with a, MCC-340 Multiskan Labsystem ELISA microplate reader (Finland). Healthy $N$. benthamiana sap extracted in ELISA extraction buffer was used as a negative control. A reaction was considered positive only if the absorbance was more than three times the mean of the negative control. The serological reagents used in ELISA revealed little cross reactivity with other virus species in the same genera. Mechanical transmission to test plants was done for selected ELISA 
positives; samples showing maximum absorbance in ELISA to each virus isolates were selected for mechanical inoculation to indicator host plants. Samples were prepared by grinding $1 \mathrm{~g}$ of leaf sap in icecold $0.1 \mathrm{M}$ potassium phosphate buffer, $\mathrm{pH}$ 7.0, containing $0.15 \%$ 2-mercaptoethanol. Samples were inoculated to $N$. benthamiana, Datura stramonium, D. metel, and Vigna unguiculata (cv. Mashad). The test plants were kept in an insect-proof greenhouse at a constant temperature of 23 to $25^{\circ} \mathrm{C}$. Symptoms on indicator hosts were recorded every 2 days for 14 days after inoculation and twice a week for the following 30 days. The indicator plants then were tested to confirm the presence of a particular virus, and to test for symptomless infections. For electron microscopy, crude plant extracts of symptomatic $N$. benthamiana test plants were prepared in $0.1 \mathrm{M}$ phosphate buffer and applied to carbon-coated copper grids. The grids then were washed with distilled water, negatively stained with a few drops of $1 \%$ uranyl acetate, and examined for the presence of tospovirus-like particles using a Zeiss-906 model transmission electron microscope.

\section{RESULTS}

Presence of tospoviruses in natural hosts. All four tospoviruses-INSV, IYSV, TSWV, and ToVV-were detected in ornamentals and weed species in the two main ornamental-growing regions of Iran (Table 1). Of the 513 samples assayed, 168 reacted positively in ELISA. In Tehran, INSV was identified in 21 samples $(10 \%)$, IYSV in 4 samples (2\%), TSWV in 16 samples $(8 \%)$, and ToVV in 22 samples (11\%). In Markazi province, INSV was identified in 24 samples (8\%), IYSV in 1 sample $(0.5 \%)$, TSWV in 40 samples (13\%), and ToVV in 36 samples (12\%). Viruses were found in 46 ornamental and 7 weed plant species collected (Table 1), ToVV $(11 \%)$ was the predominant virus in samples collected from Tehran and TSWV (13\%) was predominant in Markazi province. TCSV was not detected from any of these plant samples (Table 1).

Symptom descriptions on indicator test plants for these viruses are given in Table 2. A set of different plant species from two botanical families (Solanaceae and Chenopodiaceae) were inoculated from selected ELISA-positive ornamental plants with different tospoviruses. C. amaranticolor and $V$. unguiculata showed local necrotic lesions and $N$. benthamiana gave systemic leaf deformation and mosaic symptoms to infection with four tospoviruses. TSWV inoculation to L. esculentum (cv. Avand) produced necrotic local lesions, but the virus could not be recovered from uninoculated trifoliate leaves when back indexed to $V$. unguiculata indicator test plants. No distinct symptom differences were observed after inoculation of selected isolates of the viruses to different indicator test plants. $V$. unguiculata was a good diagnostic indicator host for the tospoviruses, and symptoms expressed were informative for preliminary differentiation of the four tospoviruses. This is the first report of several new natural hosts (16) of TSWV for Iran, including an Althea sp. (Malvaceae), Cordia crenata (Boraginaceae), a Jasminum sp. (Oleaceae), Lonicera caprifolium (Caprifoliaceae), Monihot esculenta (Liliaceae), Pelargonium odoratissimum (Geraniaceae), Rosa damascene, a Rosa sp. (Roasaceae), a Scindapsus sp. (Araceae), a Tagetis sp. (Umbeliferae), and a Zinnia sp. (Ziniaceae) (Table 1).

Identification and testing of Thrips spp. Microcephallothrips abdominalis, Thrips tabaci, a Haplothrips sp., and Frankliniella tenuirnis were identified from ornamental fields (Table 3). Adults of T. tabaci collected from infested ornamentals in the Tehran region tested and were positive for ToVV (ELISA). M. abdominalis and T. tabaci commonly were found infesting ornamental plants collected from Mahallat areas and tested to be ELISA positive with TSWV, ToVV, and INSV.

Electron microscopy. Electron microscopical examination of sap extracts from selected host or infected $N$. benthamiana plants revealed the presence of typical enveloped tospovirus-like particles of 80 to $120 \mathrm{~nm}$ in diameter (T. Ghotbi, unpublished data).

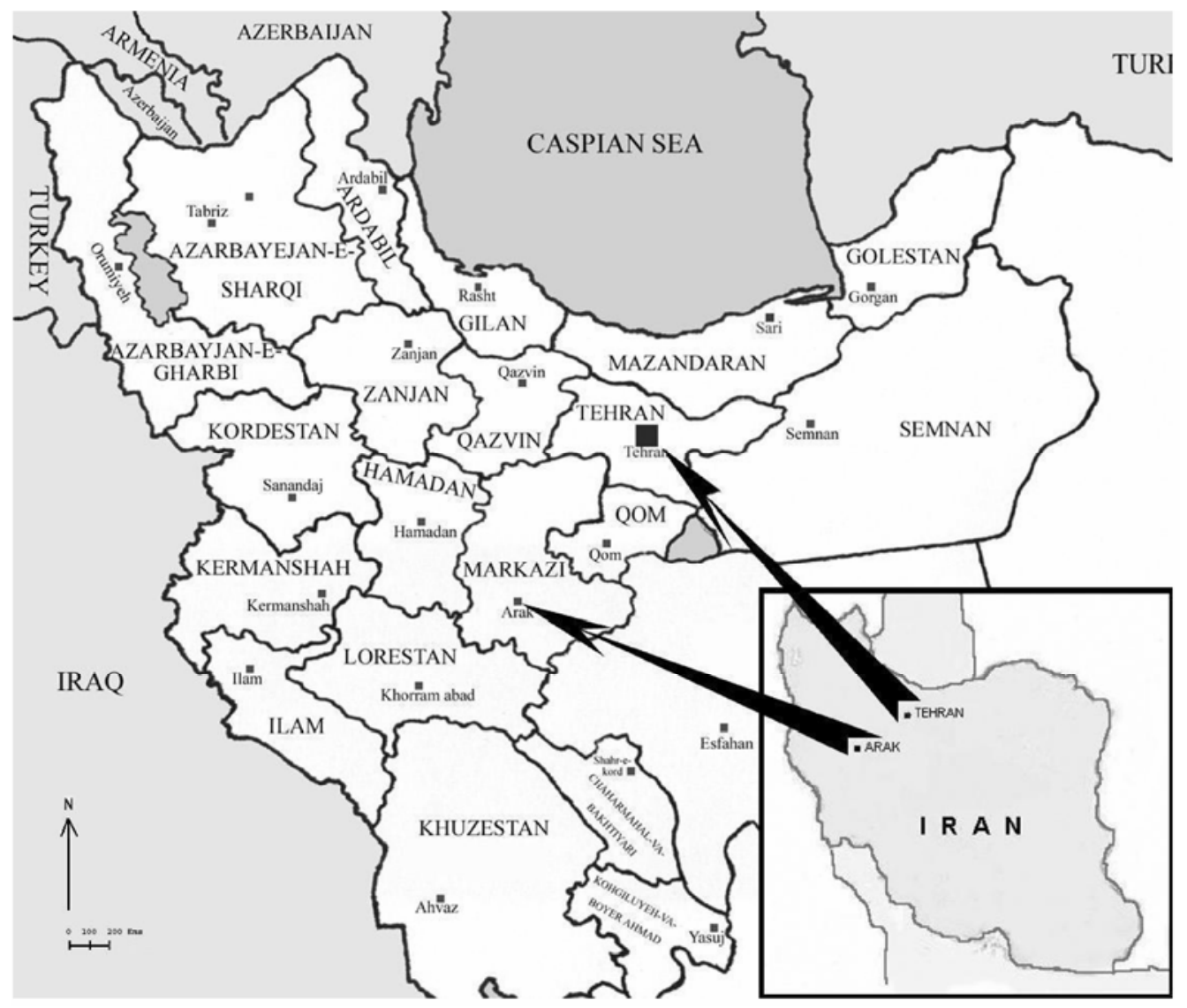

Fig. 1. Map of Iran showing the location of ornamental plants surveyed during 2000-02. 


\section{DISCUSSION}

Occurrence of TSWV in soybean, tomato, potato, tobacco, peanut, and Cineraria spp. in Iran has been reported previously $(2,8,10,15,17)$. Occurrence of INSV on ornamentals from Mahallat and Tehran provinces also has been reported (19). Our study extends the information provided in earlier reports to the natural occurrence of at least four tospoviruses, TSWV, ToVV, INSV, and IYSV, infecting different orna- mental crops and several weed species in Tehran and Markazi. INSV was found only occasionally, whereas ToVV, TSWV, and IYSV were collected quite frequently. These viruses also were found frequently in mixed virus infections (Table 1). The symptoms caused by TSWV and INSV in $N$. benthamiana and V. unguiculata were very similar to those reported by Varia et al. (20) and Gracia et al. (11). The economic impact of these viruses on ornamen- tal production remains to be assessed; however, our findings provide preliminary evidence indicating geographical distribution of the different species of tospoviruses in ornamental and weed species in Iran. Moreover, identification of putative natural virus reservoir host plant and weed species should help in control management of the viruses. The incidence of ToVV in several crops and locations suggested that this virus is of considerable epidemiological

Table 1. Occurrence of tospoviruses in ornamentals and weed hosts in Tehran and Markazi Provinces of Iran (2000-02) ${ }^{\mathrm{a}}$

\begin{tabular}{|c|c|c|c|c|c|c|c|c|c|c|c|}
\hline \multirow[b]{2}{*}{ Plant species } & \multirow[b]{2}{*}{ Total $^{\text {b }}$} & \multicolumn{5}{|c|}{ Tehran } & \multicolumn{5}{|c|}{ Markazi (Mahallat) } \\
\hline & & INSV & IYSV & TCSV & ToVV & TSWV & INSV & IYSV & TCSV & ToVV & TSWV \\
\hline \multicolumn{12}{|l|}{ Ornamentals } \\
\hline Althea sp. & 9 & _- & _- & _- & 1 & _- & 1 & - & _- & _- & 1 \\
\hline Anthemis sp. & 11 & - & - & - & - & - & 1 & - & - & - & - \\
\hline Antirrhinum sp. & 9 & - & - & - & _- & _- & - & - & - & 1 & - \\
\hline Bougainvillea sp. & 5 & 1 & - & - & - & - & - & - & - & 1 & - \\
\hline Calendula sp. & 11 & 2 & - & - & 1 & 2 & - & - & - & 1 & 1 \\
\hline Canna hortensis & 6 & - & - & - & - & - & 1 & _- & - & - & 1 \\
\hline Cheiranthus cheiri & 14 & - & - & - & 1 & - & 1 & - & - & - & - \\
\hline Chrysanthemит morifolium & 16 & 4 & - & - & 3 & _- & 3 & - & - & 2 & 2 \\
\hline Chrysanthemum prutescence & 11 & - & - & - & - & - & 1 & - & - & - & 1 \\
\hline Cineraria sp. & 15 & - & - & - & 2 & - & 1 & - & - & 1 & 1 \\
\hline Cordia crenata & 5 & - & - & - & - & - & - & - & - & - & 1 \\
\hline Cycas sp. & 8 & 1 & 1 & - & - & - & - & - & - & - & - \\
\hline Cyclamen sp. & 9 & - & - & - & 1 & 1 & - & - & - & - & - \\
\hline Dahlia sp. & 19 & - & - & - & - & - & 2 & - & - & 2 & 3 \\
\hline Dianthus sp. & 8 & - & - & _- & - & - & 1 & - & _- & 2 & 3 \\
\hline Ficus benjamina & 7 & - & - & - & 1 & 1 & 1 & - & - & 1 & - \\
\hline Gazania sp. & 11 & 1 & - & - & - & 1 & 1 & - & - & 6 & 5 \\
\hline Gladiolus sp. & 11 & 1 & - & - & - & - & - & - & - & - & - \\
\hline Gomphrena globosa & 8 & - & - & - & - & - & - & - & - & 1 & - \\
\hline Helianthus annuus & 10 & - & - & - & 1 & - & - & - & - & - & - \\
\hline Impatiens sp. & 12 & - & - & - & - & 1 & - & - & - & - & - \\
\hline Jasminum sp. & 5 & _- & _- & _- & _- & _- & _- & _- & _- & 1 & 1 \\
\hline Linda sp. & 7 & - & - & - & - & - & - & - & - & 1 & 1 \\
\hline Lonicera caprifolium & 5 & - & - & - & - & - & - & - & - & 2 & 2 \\
\hline Magnolia sp. & 8 & - & - & - & - & - & - & - & - & 1 & - \\
\hline Manihot esculenta & 6 & - & - & - & - & 1 & - & - & - & - & 1 \\
\hline Matricaria maritima & 6 & 1 & - & - & _- & - & _- & - & - & - & - \\
\hline Oenothera biennis & 8 & - & - & - & - & - & - & - & - & - & 1 \\
\hline Pelargonium hortorum & 18 & - & 1 & - & - & 1 & 2 & 1 & - & 2 & 2 \\
\hline Pelargonium odoratissimum & 15 & - & - & - & 1 & - & - & - & - & 2 & 1 \\
\hline Petunia sp. & 11 & - & - & - & - & - & - & - & - & - & 1 \\
\hline Rosa damascene & 15 & - & - & - & 1 & 1 & - & - & - & - & - \\
\hline Rosa sp. & 18 & 1 & 1 & - & 2 & 1 & 1 & - & - & 1 & 3 \\
\hline Rosmarinus officinalis & 10 & - & - & - & 2 & 2 & - & _- & - & - & - \\
\hline Rudbeckia sp. & 11 & - & - & - & - & - & - & - & - & - & 1 \\
\hline Saintpaulia ioantha & 11 & 1 & - & _- & 1 & - & 3 & - & _- & 1 & 1 \\
\hline Salvia sp. & 15 & - & - & - & - & - & 1 & - & - & - & 1 \\
\hline Scindapsus sp. & 9 & 2 & 1 & - & - & 1 & - & - & - & - & - \\
\hline Schefflera sp. & 7 & - & - & - & - & 1 & - & - & - & - & - \\
\hline Spathiphyllum sp. & 6 & 1 & - & - & - & - & - & - & - & - & - \\
\hline Syngonium podophyllum & 9 & 1 & - & _- & - & - & - & - & _- & - & - \\
\hline Tagetes sp. & 10 & - & - & - & - & - & - & - & - & 2 & 1 \\
\hline Tropaeolum majus & 7 & - & - & - & - & 1 & - & - & - & 1 & 1 \\
\hline Verbena sp. & 8 & - & - & - & - & - & - & - & - & 1 & - \\
\hline Viola sp. & 9 & 3 & - & - & - & - & - & - & - & - & - \\
\hline Zinnia sp. & 10 & 1 & - & - & - & 1 & - & - & - & - & - \\
\hline \multicolumn{12}{|l|}{ Weeds } \\
\hline Amaranthus sp. & 9 & - & - & - & 1 & - & _- & - & - & 1 & - \\
\hline Chenopodium album & 11 & - & - & - & 1 & - & 1 & - & - & - & 1 \\
\hline Cuscuta sp. & 8 & _- & _- & _- & 1 & _- & _- & _- & _- & _- & - \\
\hline Euphorbia seguieriana & 9 & - & - & - & - & - & 1 & - & - & 1 & - \\
\hline Lactuca aculeata & 4 & - & - & - & - & - & - & - & - & 1 & - \\
\hline Lavandula sp. & 5 & - & - & - & - & _- & 1 & - & - & - & - \\
\hline Portulaca oleracea & 8 & - & - & - & 1 & - & - & - & - & - & - \\
\hline Total incidence & 513 & $10 \%$ & $2 \%$ & $0 \%$ & $11 \%$ & $8 \%$ & $8 \%$ & $0.5 \%$ & $0 \%$ & $12 \%$ & $13 \%$ \\
\hline
\end{tabular}

${ }^{a}$ Number of samples in which virus was found; - = negative in all samples tested. INSV = Impatiens necrotic spot virus, IYSV = Iris yellow spot virus, $\mathrm{TCSV}=$ Tomato chlorotic spot virus, ToVV = Tomato Varamin virus, TSWV = Tomato spotted wilt virus .

$\mathrm{b}$ Total number of plants tested. 
Table 2. Host range studies of different Tospovirus spp. ${ }^{\mathrm{a}}$

\begin{tabular}{|c|c|c|c|c|c|c|c|c|}
\hline \multirow[b]{2}{*}{ Indicator host plants } & \multicolumn{2}{|c|}{ TSWV } & \multicolumn{2}{|c|}{ ToVV } & \multicolumn{2}{|c|}{ IYSV } & \multicolumn{2}{|c|}{ INSV } \\
\hline & $\mathbf{L}$ & $\mathbf{S}$ & $\mathbf{L}$ & $\mathbf{S}$ & $\mathbf{L}$ & $\mathbf{S}$ & $\mathbf{L}$ & $\mathbf{S}$ \\
\hline Nicotiana benthamiana & NL, NRS & LD, Mo & $\cdots$ & LD & $\ldots$ & LD & NL & CHL, LD, De \\
\hline N. rustica & SNL, NRS & VCL, Mo & $\mathrm{NL}$ & LD & $\ldots$ & $\ldots$ & $\ldots$ & $\ldots$ \\
\hline N. tabacum (cv. Samsun) & $\mathrm{NL}$ & CL, Mo & $\ldots$ & LD & $\ldots$ & $\ldots$ & $\ldots$ & CL, Mo \\
\hline Vigna unguiculata & NL, NRS & $\mathrm{LD}, \mathrm{MNL}$ & MNL & $\ldots$ & $\ldots$ & MNL, NRS & MNL & $\ldots$ \\
\hline Datura metel & NL, NRS & LD & CL, CRS & LD & $\ldots$ & $\ldots$ & CL, CRS & LD, Mo \\
\hline D. stramonium & NL, NRS & LD, Mom, De & $\ldots$ & LD & $\ldots$ & $\ldots$ & CL, CRS & CHL, Mo \\
\hline Petunia hybrida & NL & $\ldots$ & NL & $\ldots$ & NL & $\ldots$ & NT & NT \\
\hline Lycopersicon esculentum (cv. Avand) & NL & (Mo) & NL & Mo & $\ldots$ & $\ldots$ & $\ldots$ & $\ldots$ \\
\hline Chenopodium amaranticolor & NL & $\ldots$ & NL & $\ldots$ & $\ldots$ & $\ldots$ & NL & NL, NRS \\
\hline
\end{tabular}

a One sample from each of four different Tospovirus isolates showing maximum absorbance in enzyme-linked immunosorbent assay was selected for mechanical inoculation to indicator host plants. TSWV $=$ Tomato spotted wilt virus, ToVV $=$ Tomato Varamin virus, IYSV $=$ Iris yellow spot virus, INSV $=$ Impatiens necrotic spot virus, $\mathrm{L}=$ local symptom, $\mathrm{S}=$ systemic, $\mathrm{CHL}=$ chlorosis, $\mathrm{CL}=$ chlorotic lesion, $\mathrm{CRS}=\mathrm{chlorotic}$ ring spot, $\mathrm{De}=$ plant death, $\mathrm{LD}=$ leaf deformation, $\mathrm{MCL}=$ mild chlorosis, $\mathrm{MNL}=$ mild necrotic lesion, $\mathrm{Mo}=$ mosaic, $\mathrm{NL}=$ necrotic lesion, $\mathrm{NT}=$ not tested, NRS $=$ necrotic ring spot, $\mathrm{SNL}$ $=$ severe necrotic lesion, and $\mathrm{VCL}=$ vein clearing.

Table 3. Vector status of populations of Thrips spp. in Tehran and Markazi provinces of Iran ${ }^{\mathrm{a}}$

\begin{tabular}{|c|c|c|}
\hline Region, plant species & Thrips spp. & ELISA test result ${ }^{b}$ \\
\hline \multicolumn{3}{|l|}{ Markazi } \\
\hline Althea sp. & $\begin{array}{l}\text { Microcephalothrips abdominalis Crow., } \\
\text { Thrips tabaci Lind. }\end{array}$ & TSWV* \\
\hline Antirrhinum sp. & T. tabaci Lind. & - \\
\hline Calendula sp. & M. abdominalis Crow., T. tabaci Lind. & ToVV-TSWV* \\
\hline Chrysanthemum sp. & T. tabaci Lind. & INSV-TSWV \\
\hline Chrysanthemum sp. & M. abdominalis & - \\
\hline Cropsis sp. & T. tabaci Lind. & - \\
\hline Dahlia sp. & T. tabaci Lind. & TSWV \\
\hline Dianthus sp. & T. tabaci Lind. & TSWV \\
\hline Gaillardia grandiflora & M. abdominalis Crow., T. tabaci Lind. & - \\
\hline Gladiolus sp. & T. tabaci Lind. & - \\
\hline Gomphrena globosa & T. tabaci Lind. & - \\
\hline Pelargonium $\times$ hortorum & T. tabaci Lind. & ToVV \\
\hline Petunia hybrida & T. tabaci Lind. & TSWV \\
\hline Rosa sp. & M. abdominalis Crow. & TSWV \\
\hline Rudbeckia sp. & T. tabaci Lind., Haplothrips sp. & TSWV* \\
\hline Tagetes sp. & T. tabaci Lind. & ToVV \\
\hline Tropaeolum majus & T. tabaci Lind. & ToVV- TSWV \\
\hline \multicolumn{3}{|l|}{ Tehran } \\
\hline Chrysanthemum sp. & T. tabaci Lind. & ToVV \\
\hline Polianthes sp. & T. tabaci Lind., Frankliniella tenuirnis Uzel. & - \\
\hline Rosa sp. & T. tabaci Lind., F. tenuirnis Uzel. & ToVV* \\
\hline Tagetes sp. & T. tabaci Lind. & ToVV \\
\hline
\end{tabular}

a Plant species from which thrips were sampled are indicated.

b ELISA = enzyme-linked immunosorbent assay, TSWV = Tomato spotted wilt virus, ToVV = Tomato Varamin virus, INSV = Impatiens necrotic spot virus, $*=$ positive ELISA results obtained from a mixed population of Thrips spp. (extract was a mixture from both the thrips spp.), and - = negative.

significance. ToVV, which was characterized only recently (21), has been largely overlooked in earlier studies because antiserum was not available. Although the host range of this virus appears to be as broad as that of TSWV, it is easily distinguished from TSWV by ELISA and host plant reaction. Further studies are needed to describe the epidemiological characteristics, including vector transmission of this new virus from Iran. ToVV was present in T. tabaci from ornamentals in Tehran and TSWV, ToVV, and INSV were present in T. tabaci and M. abdominalis from ornamentals in Mahallat. These results coincide with the rate of occurrence of these viruses in these two regions. The two species have been reported as vectors of tospoviruses elsewhere $(9,18)$. T. tabaci was the more common species. However, F. occidentalis, a primary Tospovirus vector species (18), was not identified from thrips populations from Iran, suggesting that ornamental plants in these areas are not yet infested with $F$. occidentalis. We sampled only two regions in Iran for thrips and, therefore, do not understand why the prevalence of Tospovirus spp. differs in separate geographic areas. The presence of more than one virus species in each geographical area might be attributed to the presence of different thrips species acting as vectors of these viruses. The lack of information on vector species and their distribution, virus transmission efficiencies, and further biological characteristics of the vectors in Iran warrant further investigation. The detection of a new virus species in Iran, ToVV, encourages the use of virus identification approaches using multiple indexing methods, including biological and infectivity assays. This will aid in a comprehensive understanding of the complex virus situation present and of putative unknown virus species, strains, and variants.

\section{ACKNOWLEDGMENTS}

We thank A. H. Mehraban, H. Bayat (Agricultural Research Centre, Markazi province), D Shahriari, and M. A. Ghasemi (Agricultural Research Centre, Varamin) for collecting samples; M. Afzali for his assistance with greenhouse plants; and S. Sajedi and F. Aghabaigee, Botany Department (PPDRI), for their assistance in identification of weed species.

\section{LITERATURE CITED}

1. Abbasifar, A. K. 2003. Pages 1-3 in: Proc. Second Natl. Sci. Semin. Ornamental Crops Flowers. Mahallat, Iran.

2. Bananej, K., Shahraeen, N., Ahoonmanesh, A., Lesemann, D. E., and Shahriari, D. 1988. Identification of Tomato spotted wilt virus from tomato fields in Varamin area, Iran. Iran. J. Plant Pathol. 34:30.

3. Bezzera, I. C., Resende, R. de O., Pozzer, L., Nagata, T., Kormerlink, R., and DeAvila, A. C. 1999. Increase of tospoviral diversity in Brazil with the identification of two new tospovirus species, one from chrysanthemum and one from zucchini. Phytopathology 89:823-830.

4. Cho, J. J., Mau, R. F. L., Hamasaki, R. T., and Gonsalves, D. 1988. Detection of Tomato spotted wilt virus in individual thrips by enzymelinked immunosorbent assay. Phytopathology 78:1384-1352.

5. Clark, M. F., and Adams, A. N. 1977. Characterization of microplate method of enzymelinked immunosorbent assay for the detection of plant viruses. J. Gen. Virol. 34:475-483.

6. Cortez, I., Saaijer, J., Wongjkaew, K. S. A., Pereira, M., and Goldbach, R. 2001. Identification and characterization of a novel tospovirus species using a new RT-PCR approach. Arch. Virol. 146:265-278

7. Dijkstra, M. J., and de Jager, P. C. 1998. Practical Plant Virology. Protocols and Exercises. Springer Verlag.

8. Farzadfar, S., Golnaraghi, A. R., and Pourrahim, R. 2002. Plant Viruses of Iran. Saman Company Publication, Tehran, Iran

9. Goldbach, R., and Kuo, G. 1996. Introduction, proceedings of symposium on tospoviruses and thrips of floral and vegetable crops. Acta Hortic. 431:21-26.

10. Golnaraghi, A. R., Shahraeen, N., Pourrahim, R., and Farzadfar, Sh. 2001. First report of tomato spotted wilt virus on soybean in Iran. Plant Dis. 85:1290.

11. Gracia, O., Borbon, D. I. C., Granym, M. N., Millan, D. E., and Ceesta, G. N. 1999. Occurrence of different tospoviruses in vegetable crops in Argentina. J. Phytopathol. 147:223-227.

12. Habibi, K. M., Mosahabi, G., and Okhovat, M. 
1988. Identification of viruses infecting tomato in Varamin. Page 195 in: Proc. 13th Iran. Plant Prot. Congr. Karaj, Tehran, Iran.

13. Jain, R. K., Pappu, H. R., Pappu, S. S., Krishna Reddy, M., and Vani, A. 1988. Watermelon bud necrosis tospovirus is a distinct virus species belonging to serogroup lV. Arch. Virol. 143:1637-1644.

14. McMichael, L. A., Persley, D. M., and Thomas, J. E. 2002. A new tospovirus serogroup IV species infecting capsicum and tomato in Queensland, Australia. Australas. Plant Pathol. 31:231-239.

15. Moeini, A. A., Sahandpour, A., and Izadpanah, K. 1998. Identification of Tomato spotted wilt virus (TSWV) in ornamental plants and tomato in Shiraz. Page 199 in: Proc. 13th Iran. Plant Prot. Congr. Karaj, Tehran, Iran.

16. Parrella, G., Gognalons, P., Gebre-Selassie, K., Vovlas C., and Marchoux, G. 2003. An update of the host range of Tomato spotted wilt virus. J. Plant Pathol. 85:227-264.

17. Pourrahim, R., Farzadfar, Sh., Moeini, A. A., Shahraeen, N., and Ahoonmanesh, A. 2001. First report of Tomato spotted wilt virus on potatoes in Iran. Plant Dis. 85:442.

18. Prins, M., and Goldbach R. 1998. The emerging problem of tospovirus infection and nonconventional methods of control. Trends Microbiol. 6:31-35.
19. Shahraeen, N., Ghotbi, T., and. Mehraban, A H. 2002. Occurrence of Impatiens necrotic spot virus in ornamentals in Mahallat and Tehran provinces in Iran. Plant Dis. 86:694.

20. Vaira, A. M., Roggero, P., Luisoni, E., Masenga, R., and Milne, G. 1993. Characterization of two tospoviruses in Italy: Tomato spotted wilt and Impatiens necrotic spot. Plant Pathol. 42:530-542.

21. Winter, S., Koerbler, M., Shahraeen, N., Katul, L., and Lesemann, D. E. 2002. Characterization of a new tospovirus species infecting tomato in Iran. Page 120 in: Proc. First Joint Conf. Int. Working Group Legumes Vegetable Viruses. Bonn, Germany. 